Article

\title{
From Good Time Girl to Damsel in Distress: Protecting the British War Bride in the United States, 1944-1950
}

\author{
Gail Savage \\ Department of History, St. Mary's College of Maryland, St. Mary's City, MD 20686, USA; glsavage@smcm.edu \\ Received: 27 September 2020; Accepted: 25 November 2020; Published: 30 November 2020 \\ check for \\ updates
}

\begin{abstract}
During the Second World War, the United Kingdom became an epicenter of transnational, especially transatlantic, marriages, but not all these marriages proved successful. As one disappointed English war bride on her way back home expressed herself, she was "Too shocked to bring her baby up on the black tracks of a West Virginia mining town as against her own home in English countryside of rose-covered fences." This essay examines the government program developed to provide financial aid and legal advice to British women estranged from or abandoned by their American husbands from the passage of the 1944 Matrimonial Causes (War Marriages) Act to its winding down in 1950. The analysis draws upon a wide range of documents to survey the formulation and implementation of the government response and to consider some illustrative cases dealt with by British consular officials in the United States. These examples illuminate the gap between human behavior envisioned by policy-makers and the more varied behavior encountered by those who carried out the duties charged to them. The cases thus represent the nexus between state intervention and the individual experience of larger-scale social dynamics set off by war and the global movement of populations.
\end{abstract}

Keywords: marriage; divorce; Second World War; social policy; Anglo-American relations

\section{Introduction}

The war effort in Britain entailed long years of service abroad for thousands of men, evacuation of children from cities to the countryside, and the employment of women, even married women, in war work, putting considerable strain on marital and familial ties (Field 1990). The rapid increase in divorce litigation during the war years provided one disturbing expression of this. The number of divorces swelled from 6200 in 1938 to over 10,000 in 1943 to 60,300 in 1947 (Stone 1990, Table 13.1, p. 435). Wartime conditions stimulated marriages as well as divorces (Ferguson and Fitzgerald 1954, p. 19; Modell and Steffey 1988), and marriages to foreigners formed an important aspect of the complex impact of war on British family life. Large numbers of British women married not only Americans, but also Canadians, Poles, French, Norwegians, and others. Efforts to discourage such marriages proved fruitless. Transnational marriages became a large-scale phenomenon with some 37,849 UK women marrying American servicemen (Reynolds 2000, p. 421). Even more marriages $(40,886)$ took place between Canadian men and British women (Keshen 2004, p. 232). If rising divorce rates unsettled observers, so did the spectacle of so many British women marrying foreigners. British troops, deployed abroad, feared and resented the competition for the affections of British women (Allport 2010, pp. 90-93; Goodman 1998, pp. 288-89; Coward 1954, pp. 260-61). ${ }^{1}$ On the home front,

1 Urquhart (1951) novel about wartime Scotland, Jezebel's Dust (1951), vividly depicts Polish and Free French soldiers as preying on innocent Scottish "girls." 
the "goodtime" girl who sought sexual relationships with foreigners outside marriage became a figure of community disapprobation (Rose 2003, pp. 71-92). The central character in the 1948 film Good-time Girl, Gwen Rawlings spiraled downward, reaching the lowest level of her degradation by joining with two American GI deserters to mug and rob those they encountered on the streets. Romances between British women and African American GIs aroused particular concern, and these have received considerable scholarly attention (Bland 2019; Topping 2013; Reynolds 2007; Rose 1997; Saunders and Taylor 1995; for the foundational work, see Smith 1987). "Sexual patriotism," as Wendy Webster has named it, required fidelity to British men, and having a relationship with any foreigner was regarded with suspicion and disapproval, with the deepest hostility directed towards Poles, Italian POWs, and American troops in general, not just African Americans (Webster 2013).

In contention with this judgmental view of women who formed relationships with foreigners, British women were also featured as potential victims of predatory foreign men. Once married, British women lost the protection of a legal regime that automatically deprived them of their British domicile and citizenship status, thus placing them outside the divorce jurisdiction of English and Scottish courts (Baldwin 2001). Discussion of wartime special legislation to remediate this problem took place in the Lord Chancellor's Office during the spring of 1944, ultimately leading to the passage of the 1944 Matrimonial Causes (War Marriages) Act in October of that year. This legislation temporarily allowed British women to petition for divorce from their foreign husbands in English and Scottish courts. ${ }^{2}$ The 1944 legislation applied to marriages of British women to men domiciled outside the UK between 3 September 1939 and a future appointed day, eventually specified as 1 June 1950 (Anon 1950). ${ }^{3}$

Attaching a time limit to this loophole addressed an immediate problem without challenging the long-held principles that the domicile of the husband controlled the domicile of the wife and that domicile in turn defined divorce jurisdiction. Lord Merriman, the President of the Divorce Court, who opposed the erosion of these principles, recognized the motive for the legislation as alleviating the "hardship of the wife." However, he worried about good intentions leading to "establishing a temporary 'Reno'" from which it might be difficult to retreat after the war. ${ }^{4}$ Merriman's view did not carry the day against those who, like Parliamentary Counsel John Rowlett, wanted to ensure justice for the "wronged English girl," especially those wronged by "a man who has refused to take his new wife home to his own country." ${ }^{\prime 5}$ Before the programs stemming from the 1944 Act wound down, the passage of the 1949 Law Reform (Miscellaneous Provisions) Act made permanent this provisional access to British and Scottish divorce courts by allowing a British wife married to a man domiciled elsewhere to petition for divorce, provided she had been a resident in Britain for at least the previous three years (Graveson 1950).

The 1944 Act did not explicitly target Anglo-American marriages, but the American case was especially important in the British view because of the considerable distrust of the way that the American legal system treated divorce. The wide variation of divorce law from state to state, combined with the comparative leniency of divorce law, fueled concerns that American courts would cooperate with American husbands who wished to abandon their British wives without any notice. ${ }^{6}$ The legal advisor to the British consulate in Chicago gave a blunter assessment of the American legal environment: “... marriage and divorce laws in the United States are in a chaotic condition with no semblance of

2 For an overview of the bill see the introduction of the second reading to the House of Lords by the Lord Chancellor, John Simon. 1994. Matrimonial Causes (War Marriages) Bill. House of Lords Debates, 5 October 1944, vol. 133, cc 393-402.

3 The National Archives [TNA] FO 372/6981, “Matrimonial Causes (War Marriages) Act, 1944," Rieu to Foreign Office, 2 January 1950.

4 TNA J86/166, “Matrimonial Causes (War Marriages) Act,” Merriman to Schuster, 26 July 1944.

TNA J86/166, “Matrimonial Causes (War Marriages) Act," Rowlett to Rieu, 2 October 1944.

6 TNA FO 371/68045B, "Legal Aid to GI Brides," sub-file "Provision of legal aid to women from UK married to Canadian service or ex-service men involved in matrimonial proceedings," J. J. S. Garner to Sir Charles Dixon, 22 March 1948, details the weaknesses of American divorce practices as compared to the situation in Canada. 
equity or justice, or even decency."7 The circumstances that inspired the passage of the 1944 act also led to the extension of legal aid and advice to both those British women married to American servicemen who remained in the UK and those who followed their American husbands to the United States and found themselves in matrimonial proceedings there. The predicaments of the Anglo-American couples whose marriages floundered in the first years of peace shows that the transatlantic entanglements necessitated by the war effort proved challenging to disentangle in the immediate post-war period. Government intervention on behalf of British women required both a re-thinking of the legal framework for marriages between British women and foreigners and deployment of social services on both sides of the Atlantic to provide a pathway for them to be reincorporated into the nation.

The analysis that follows first considers the response of the government to the growing problem of failed marriages between British women and American servicemen. This draws upon a wide range of documentary materials to examine the discussions among officials at the relevant government departments, especially the Foreign Office, the Home Office, and the Lord Chancellor's Office. Policies formulated in London, in part in response to public pressure, became the responsibility of the Foreign Office's consular service to carry out. The second stage of the analysis utilizes the reports by consular officials in the United States to document their efforts on behalf of British women whose relationships with American servicemen had failed. Officials worked to obtain maintenance for the illegitimate children fathered by American servicemen and to facilitate divorces initiated by British women who wished to bring their marriages to an end. These reports, which often included transcripts of correspondence by the parties themselves, provide rich documentation of the varied circumstances of the couples that came to the attention of consular officials and the difficulties raised by the refusal of so many to conform to official expectations. The documents thus preserve not only the voices of officials but also those of the men and women whose plight attracted government attention, showing the ways in which they took an active role in their own lives, sometimes to the frustration of those who sought to help them.

\section{Saving the Wronged War Bride}

In 1945, all governments focused primarily on the demands of demobilization and the logistics of the transportation of servicemen home while wives and fiancées sought to join their husbands across the Atlantic (Reynolds 2000, pp. 417-20). The domestic difficulties of British women married to Americans soon manifested themselves, and 1946 became the pivotal year in the development of a government response as political pressure grew, both inside and outside of Parliament, to do something to help British women abandoned by their American husbands or lovers. The Married Women's Association (MWA) mounted a campaign to bring attention to the plight of British women left behind by their American husbands and then subject to divorce proceedings in the United States. They sent appeals to President Truman, Mrs. Roosevelt, and the Pope. ${ }^{8}$ The MWA also approached both the Foreign Office and the Attorney General, Hartley Shawcross. When Shawcross asked for advice about this from Foreign Secretary Ernest Bevin, Bevin assured him that the issue was under "urgent examination." ${ }^{9}$ In addition, the MWA solicited women in need of legal aid to get in touch with the group, announcing that they had received 200 applications for help at the beginning of March. ${ }^{10}$ The National Council for the Unmarried Mother and Her Child also pressed the government on the

7 TNA LCO 2/3416, “Position of British women married to American servicemen in divorce,” W. H. Gallienne, 13 April 1946.

8 TNA FO 371/51617, Newspaper cuttings: “Brides tackle Truman,” Daily Herald, 15 February 1946; “Divorce of G. I. Brides," Times, 13 February 1946; “G. I. Brides see Ambassador on Divorce Threats," News Chronicle, 16 February 1946.

9 TNA FO 371/51617, “Divorce Proceedings instituted by U. S. Servicemen against their wives in U.K," Shawcross to Bevin, 15 February 1946; Bevin's private secretary to Shawcross, 16 February 1946.

10 TNA FO 371/51619, newspaper cutting: “Legal Aid to G. I. Wives: Advice on Divorce," The Star, 4 March 1946. 
issue of maintenance, recommending that mothers of children fathered by American servicemen should get in touch with the Foreign Office. ${ }^{11}$

As part of this campaign, the MWA sought a meeting with John G. Winant, the American ambassador to the UK from March 1941 (Olson 2010). Winant expressed his sympathies to the delegation from the MWA that he received on February 16, but he made no public commitment about taking action, which left them dissatisfied. ${ }^{12}$ Winant, more interested in the development of the new United Nations than the problems of G. I. brides, was coming to the end of his tenure as an ambassador (Bellush 1968, p. 214). The next month he resigned and returned to the United States (Olson 2010, pp. 375-77). Despite the imminence of his departure, Winant opened conversations behind the scenes with British authorities immediately after the visit of the MWA delegation, asking the American Advocate General, Brigadier General Edward Betts, to raise the matter with Sir Thomas Barnes, the Treasury Solicitor. ${ }^{13}$ This initiated policy discussions that unfolded during the course of the year.

Five interdepartmental meetings took place in February (19, 21-23, 28 February), the first one held only three days after the MWA visited Winant. The British Embassy convened a meeting of its consular officials in Washington on March 28th. Three more meetings were held in London later in the year, June 4, November 21, and December 11. By the end of the year, these discussions established policies for dealing with failed marriages/relationships between British women and American servicemen. The February 21st meeting, initiated by the Treasury Solicitor Sir Thomas Barnes, considered the issue that moved Winant to ask Betts to consult with Barnes: "A number of these women were asking the U.S. Embassy for passages over to the U.S. for the purpose of defending proceedings." Normally, a British woman was not allowed to go to the U.S. unless someone certified that they were responsible for her maintenance; in these circumstances, such assurances were unlikely to be forthcoming. Barnes also thought it undesirable for the British to authorize them to go when they might find themselves "stranded and without aid in a somewhat hostile atmosphere." Barnes raised two further issues, the plight of a woman left in the UK when her erstwhile husband did not take proceedings against her but also did not maintain her as well as the question of illegitimate children fathered by American servicemen. This articulation of the issues set the agenda for subsequent discussions about what actions the government should take. ${ }^{14}$

Early on both American and British authorities agreed to some importance of addressing these issues. General Betts and Lord Chancellor Lord Jowitt met on 22 February and concurred that though the volume of problem marriages might be small, perhaps only 300 cases out of the very large number of Anglo-American marriages, the action was still necessary. George Coldstream, the Second Secretary of the Lord Chancellor's Office, summarized their conclusions for the benefit of Treasury officials: "on general grounds of humanity and in the interests of good relations between the two countries, neither the American Government nor the British Government ought to leave matters completely unattended by official cognizance." Coldstream alerted the Treasury to the possibility of the future need for funding any program that might be undertaken. He stressed the hardness of the circumstances of the women who, while waiting for transportation to reunite with their husbands, received instead a notification of divorce. He also underlined the interest of the Lord Chancellor in doing something for them and the consensus that: " ... something ought to be done on behalf of H.M.G. for the women concerned if in the event it proves feasible to do anything at all."15

11 TNA FO 371/51619, "Problems related to GI Brides," Miss Gladys Ellis to Foreign Office, 24 March 1946.

12 TNA FO 371/51617, newspaper cutting: "Ambassador 'Sympathetic but Negative'" Manchester Guardian, 16 February 1946.

13 TNA FO 371/51617, "Divorce Proceedings Instituted by US Servicemen against G. I. Brides," Coldstream to Paul Mason, 20 February 1946.

14 TNA LCO 2/3416, "Position of British women married to American servicemen in divorce," "Notes on Meeting re: G. I. Brides," 21 February 1946.

15 TNA LCO 2/3416, "Position of British women married to American servicemen in divorce," Coldstream to G. E. A. Grey, 22 February 1946; “Notes on Meeting re: G. I. Brides," 21 February 1946. 
The civil servants' party to these discussions quickly settled on a division of labor among government departments. The Foreign Office, through its consular service, agreed to deal with matrimonial proceedings in the USA as well as to notify wives of those proceedings. The Home Office took the lead in convening interdepartmental policy discussions and oversaw the welfare of wives and children in the $\mathrm{UK}^{16}$ as well as efforts on behalf of illegitimate children. The Lord Chancellor's Office approached the Law Society about extending its Services Divorce Department, created early in the war to give legal advice to those in the services involved in divorce proceedings, to include representing British wives of American husbands in divorce actions. ${ }^{17}$ Maintenance, whether of the British wife divorced or deserted, or of illegitimate children left behind by American servicemen fathers, also became an issue of broad concern. The Foreign Office had already received letters of inquiry from mothers of illegitimate children, some written at the suggestion of the National Council of the Unmarried Mother and Her Child. ${ }^{18}$ Absent support from the American husbands and fathers or from the American government, these women and children threatened to become a charge on public assistance and the British rate-payer. ${ }^{19}$ The group at the February 21st meeting agreed that an attempt should be made to get the American government to make some provision for these children, especially as any support from an individual American father only lasted until 6 months after a soldier's demobilization. ${ }^{20}$ Without enforcement mechanisms for alimony and maintenance orders, any such scheme might be futile, but Treasury Solicitor Barnes nevertheless believed that "the Government could do nothing for the G.I. Brides, and that it was essential for every possibility to be examined even though the position appeared hopeless." 21

Despite this consensus, some strains between the Home Office and the Foreign Office emerged. The Home Office placed more importance on extracting maintenance for illegitimate children from the Americans than the Foreign Office, and Home Office officials advocated a more aggressive stance towards the Americans to achieve this end. At the February 23 meeting, for instance, the strong-minded second secretary of the Home Office, Sir Frank Newsam, invited the attendance of Betts and a representative of the American Embassy to the Home Office to meet with representatives of concerned departments and then took the opportunity to inform the Americans that support for the wives and children left behind should come from American funds, either directly or indirectly by payments to a charity such as the Red Cross. Newsam recognized how many difficulties stood in the way of British women conducting divorce proceedings in the US, but he contended that "... the question of divorce was not nearly so important in these cases as the question of maintenance." 22 During the large and important November 21 meeting, Newsam again made a strong statement about what should be done with respect to the obligation of the United States and Canada to provide maintenance to the children fathered by their servicemen. In Newsam's view, the time had come to insist that the Americans reply to the British request for financial assistance. This stance accords with Newsam's previous record of pushing back against American wishes on points of contention between British governmental and American military authorities on policy regarding the spread of VD and the incidence of prostitution (Rose 1998, pp. 890, 895; Reynolds 2000, pp. 204, 206).

The Foreign Office and the Lord Chancellors Office both had reservations about this aggressive approach. During the November 21st meeting, M. G. Middleton, a Foreign Office official from

16 TNA FO 371/51617, "Minute of Meeting 19 February 1946."

17 TNA LCO 2/3416, "Notes on Meeting re: G. I. Brides," 21 February 1946.

18 TNA LCO 2/3416, "Notes on Meeting re: G. I. Brides," 21 February 1946, for an example of one such letter see TNA FO 371/51619 for that from Miss Gladys Ellis to the Foreign Office, 24 March 1946.

19 TNA FO 371/51617, newspaper cutting, “G. I. divorces: Government urged to act," News Chronicle 13 February 1946. A resolution passed by the Dartford, Kent Board of Guardians not only expressed indignation at the behavior of the Americans they had welcomed into their midst, it also expressed alarm at the prospect of the drain on public assistance.

20 TNA LCO 2/3416, "Notes on Meeting re: G. I. Brides," 21 February 1946.

21 TNA LCO 2/3416, "Notes on meeting re: G. I. Brides," Treasury Solicitor's office, 21 February 1946.

22 TNA LCO 2/3416, "G. I. Brides: Note by the Home Office", 19 March 1946. Another account of this meeting and summary of Newsam's remarks can be found in FO 371/51617. 
the British Embassy in Washington, cautioned that the British could expect no reply to questions about maintenance for illegitimate children until January when the new congress convened. George Coldstream of the Lord Chancellor's Office pointed out that it had not previously agreed to Newsam's view and thought its law officers would balk at including affiliation orders and maintenance cases among their duties. ${ }^{23}$ The Home Office also pressed Foreign Office officials to take the question of providing funds for the maintenance of illegitimate children to the Foreign Secretary, Ernest Bevin. They hoped he could raise the matter to the American Secretary of State, James Byrnes, for an immediate answer. In the event of a negative response from the Americans, the Home Office expected a public critique of the American position. This scenario did not find a receptive audience in the Foreign Office. The British Embassy in Washington telegraphed a response: "We are reluctant to suggest this course to the Secretary of State at a time when he has so many urgent matters on his hands, at any rate, unless we are quite clear that such a move would be likely to have a beneficial effect. The State Department might well however resent being subjected to pressure at this level because (1) we should appear to be asking the United States Government to undertake an obligation which is not in accordance with usual international procedure or accepted by His Majesty's Government or other Governments in similar cases ...." The American undertaking of such a policy might form an embarrassing precedent for them in other parts of the world, and British advocacy also might well receive a hostile reception from the U. S. Congress. The Foreign Office suggested to the Embassy that an approach taken at a lower level might bear fruit, as there was some American sympathy for the problems posed to the British. ${ }^{24}$ Such lower-level discussions did take place in December 1946 between John Balfour and Dean Acheson, then Under Secretary of State, but the Americans rejected British proposals. As predicted, the Americans did not wish to set a precedent, pointing out the international ramifications of doing so and noting in particular that the Canadians had not taken on this obligation in response to British requests. ${ }^{25}$

Despite these disagreements, by the end of 1946, the Law Society agreed to set up a special department, the American Divorce Department, for legal assistance to British wives of Americans remaining in the UK. The government extended the legal aid available to wives in the UK to those in the USA, while the Treasury agreed to meet the costs of litigation. In December, Coldstream told T. G. Lund, secretary of the Law Society, to go ahead with organizing a separate branch of the Services Divorce Department to take on the American cases. ${ }^{26}$ In January 1947, Lund detailed the resources dedicated to the new office, which would be served by a staff of 40 at a cost of $£ 25,960$. The Foreign Office gave a grant-in-aid to fund the effort. The program was up and running in March 1947. ${ }^{27}$ The use of consular office legal advisors in divorce had proved satisfactory enough to authorize their work on affiliation and maintenance cases as well.

In parallel to the discussions on-going during 1946, Foreign Office officials collected information in preparation for carrying out the new duties that they foresaw. Maurice Bathurst, legal adviser to the UK embassy in Washington, wrote a lengthy memo that surveyed American divorce practice state by state, including the topics of notification of defendant wives, evidence by deposition, costs, alimony, child maintenance, and legal aid. ${ }^{28}$ In efforts to determine the scope of the problems faced by British women in the United States, the Embassy solicited information from its consulates. ${ }^{29}$ A thorough review carried out in November identified up to 623 cases. $^{30}$ This survey compiled reports from 18

\footnotetext{
23 TNA LCO 2/3416, “Note of meeting on G. I. Brides," 11 December 1946.

24 TNA LCO 2/3416, Telegram from Foreign Office to Embassy in Washington, No. 111328, 3 December 1946.

5 TNA LCO 2/3416, Telegram from Washington to Foreign Office, Lord Inverchapel, no. 7271, 22 December 1946.

TNA LCO 2/3416, Coldstream to Lund, 6 December 1946.

27 TNA LCO 2/3417, Notes of meeting with Lund at Lord Chancellor's Office, 16 January 1947; T. G. Lund to Sherwood (FO), 20 January 1947.

28 TNA FO 700/75, “Memorandum on G. I. Brides,” M. E. Bathurst, 6 March 1946.

29 TNA LCO 2/3416, Telegram No. 1835, Foreign Office to Washington, 16 February 1946.

30 TNA FO 700/75, “Embassy to Consulates," 6 September 1946; FO 2/3416, R. S. B. Best to Mrs. Edwina A Very, 23 November 1946.
} 
consulates that enumerated the ongoing cases involving British women in marital difficulties that had come to the attention of consulate officials. The form of the reports varied from consulate to consulate too much to form the basis for a rigorous, quantitative picture of the situation, but they do suggest some general characteristics of the situations encountered by consulate officials. The number of cases varied considerably from place to place. At the low end, the Cincinnati consulate reported only two cases of divorce. In contrast, large cities like Philadelphia (73), Houston (62), Cleveland (106), and New York (60) had many more cases. However, this snapshot of cases could be misleading, as the Chicago, Baltimore, and Miami consulates warned. Chicago, at the time of making their report, had only three ongoing cases of divorce, but it had had to deal with over 150 cases during the previous eight months. Baltimore reported 12 divorce cases and four maintenance cases but also commented on an ongoing fluctuation in the number of cases, with new ones coming to their attention while others went dormant when couples reconciled. Only Miami put the number of their cases in the context of the number of British "brides" in their area. Officials in Miami estimated the number of "G. I. brides" at 484, and they had seen a total of 122 divorces and 46 other kinds of issues that required legal assistance. That suggests a marital failure rate of $34 \%$, which accounts for Miami's pessimism about the future prospects of these marriages; its office estimated $25 \%$ of them failed. Miami further cautioned that not all divorce cases came to the attention of the consulate, as some wives had the means to carry on legal action without help.

Divorce cases predominated, outnumbering maintenance cases in most locations. Atlanta, for instance, reported nine divorce cases and five maintenance cases, Baltimore 12 divorce and four maintenance, Cleveland, 72 divorce and 14 maintenance cases. Only Philadelphia reported more maintenance cases than divorce cases, with 45 maintenance and 23 divorce cases. However, Philadelphia was also one of the few consulates that reported the number of wives still resident in the UK (33), who might have been more likely to be seeking maintenance. Philadelphia also reported 11 illegitimacy cases, one of the only consulates to report on this category. These numbers, however cautiously they need to be interpreted, do not tend to support Frank Newsam's contention that the importance of maintenance cases outweighed the importance of divorce cases, but once maintenance was pursued by the soon-to-be-formed American Divorce Department the number of those cases would most likely increase.

In another notable feature of these reports, consulates discussed the issue of legal aid found that local access to legal aid and other supports sufficient to sustain those in need. The Chicago consulate explained: "We have had the assistance of our own legal advisers, of the local Domestic relations Bureau, and one or two cases we have referred to the Illinois Lawyers Association Legal Aid Bureau. In other cases, both in and outside Chicago the Distressed wives have found legal aid either directly, or through recommendations by our legal advisers, the Red Cross, and other bodies ... . In general, it can be said that where legal assistance appeared advisable it has by one means or another been obtained and so we have managed to keep abreast of our cases." Despite this positive assessment, the Consulate's report expressed a wish for more assured support in this area, as identifying a source of aid took up considerable time, causing delay and increasing "distress for the wife." The Cleveland consulate also noted the helpfulness of local legal aid societies as well as social service organizations, particularly the Family Service Association. ${ }^{31}$ Perhaps the decentralized nature of US political and social service organizations led British officials to underestimate the potential for both legal aid and social services available to British women married to American men.

In addition to this survey, Foreign Office records preserve detailed accounts of some of the individual cases that came to the attention of their consular officials in the United States. These reports,

31 TNA LCO 2/3416, "Appendix I: Summaries of cases on-going in USA: BRITISH WIVES OF UNITED STATES SERVICEMEN," R. S. B. Best to Mrs. Edwina A. Avery, 23 November 1946. Best was the Legal advisor to the British Embassy and Mrs. Avery represented the legal sorority KBP, which was considering the possibility of providing legal advice to British wives in the United States. 
despite their fragmentary character, give a more intimate view of the people who sought help. They often include transcripts of correspondence written by the parties themselves, family members, and legal representatives as well as commentary by consular officials. Produced by the official intervention into individual lives marked by romantic and marital relationships made possible but also complicated by the war, these records illuminate the tensions between policy-making and personal lives. The records reveal both the official attitudes informing these policies and the extent of the agency exerted by individuals, even when individual goals, desires, and interests might have been dwarfed by the dynamics set in motion by the global war. The analysis of these case files that follows focuses first on the pursuit of maintenance for illegitimate children and then on the support provided for divorce litigation.

\section{Maintenance of Illegitimate Children}

Following the Home Office initiative, attempts to trace the American putative fathers of illegitimate children fell to consular officials. Increasing rates of illegitimacy, along with increasing rates of divorce and juvenile delinquency, generated considerable anxiety during the war (Ferguson and Fitzgerald 1954, pp. 74-141; Thane and Evans 2012, pp. 54-81). The years between 1940 and 1945 saw a rapid increase in the number of illegitimate births, with a total of 262,451 recorded, with 1944 and 1945 seeing the highest numbers (Ferguson and Fitzgerald 1954, p. 91, Table 2). Observers often linked the very large numbers of allied forces in Britain to this dramatic increase. Estimates of the nationality of the fathers suggest that Canadian servicemen were responsible for 22,000 of these children and US servicemen for another 22,000 or 23,000 (Keshen 2004, p. 233; Reynolds 2000, p. 404). ${ }^{32}$ This attracted negative attention, and MPs pressed by constituents, in turn, pressured the government to extract maintenance, especially from Canada and the USA, whose troops were responsible for so many of these births. ${ }^{33}$

Serving men in the US armed forces could voluntarily provide an allotment to the mother of their child from their pay. Alternatively, if the mother instituted a successful affiliation petition, US military authorities cooperated to make sure that the man paid. ${ }^{34}$ However such payments ceased if the man left the services and returned to civilian life. As American forces began to demobilize and return home at the end of the war, British authorities had to grapple with the requirement in most North American jurisdictions that the mothers be present to pursue affiliation suits. This posed a formidable barrier to British mothers who sought maintenance for their children. Consular officials undertook efforts to locate the American fathers and persuade them to provide support to their children. The examples included in the case files provide a poignant record of the aftermath of these wartime romances and illustrate the difficulties in extracting support directly from individual foreign putative fathers.

To begin the process, the mother had to provide evidence of paternity to local authorities. The case then went to the Home Office, who passed it to the Foreign Office, who then gave the responsibility to the local consular official nearest the father's last known address. The proof of paternity often took the form of correspondence from the man that established the relationship between the parents. Even with all this information, finding the man in the United States was difficult. For example, in February 1948, the Home Office asked the Foreign Office to make inquiries in the case of the child of Lydia Dixon, fathered by Merle E. Rice. The file included a transcript of a letter dated 15 September 1945, written shortly after Rice's return to the United States. The letter reassured Lydia of his love, saying: "My Own Darling Lydia, Just a few lines to let you know I got back home O.K .... I will do all I can to make you

32 Much uncertainly surrounds these numbers. For instance, David Reynolds cites a Life Magazine article, "The Babies They Left Behind Them: From London to Tokyo the problem of illegitimate children abandoned by our GIs is still to be solved," Life 23 April 1948, p. 41 as a source for the 22,000 figure, although the Life article does not itself cite a source.

33 See Parliamentary questions: "Canadian Service Men (Affiliation Orders)," HC Debates 27 March 1945, vol. 409, cc 1288-89; “USA Forces. United Kingdom (Affiliation Order Applications)," HC Debates 12 April 1945, vol. 409 cc $1969-70$.

34 TNA FO 371/42308, "Maintenance of illegitimate children of American forces." 
happy Darling, and the Baby also sweet ... But you know I would of [sic] married you before I left if I could ... . I will save up my love and kisses till you come to me Darling one." Perhaps these emotions cooled between 1945 and 1948 when consular officials sought to trace his whereabouts; in any case, the consulate in Denver reported that they had been unable to locate Rice. ${ }^{35}$

The pursuit of a claim against Michael Heinz by Doreen Shaughnessy for support of their child became one of four test cases to evaluate the feasibility of pursuing affiliation orders against American putative fathers. The assembled evidence to establish his paternity consisted of a photo, a partial letter Heinz sent to Shaughnessy, her statement, and statements by her parents. Heinz lived in North Dakota, so this case was overseen by the Minneapolis consulate. During 1948, the Home Office sent several letters pressing the Foreign Office to take action. A review of the case late in the year by American lawyers concluded that in their view the case was "hopeless." Heinz denied any knowledge of Shaughnessy and refused to make voluntary payments on behalf of the child. Moreover, as a farm laborer, he probably did not have sufficient means. North Dakota law did not provide any recourse even though it held putative fathers responsible for the support of their children, but the father had to acknowledge paternity. In addition, state law barred action against the father after two years from birth. ${ }^{36}$

In two of the cases described in detail, the preexisting marriage of the mother had preluded marriage of the parents. The Home Office had particular worries about the illegitimate children of married women. ${ }^{37}$ The file on Rosemary Harris and Clarence Woodrow Lamb included several long, loving letters sent by Lamb to Harris, but his desire to marry her was thwarted by her marital status. After trying and failing to arrange for either marriage or adoption, Harris returned home where he married an American woman. By the spring of 1948, he had one child and another expected, and his unstable employment made it impossible to contribute any support to his child in England, although he promised he would as soon as he was able. The file documents do not record whether Lamb followed through with that commitment. ${ }^{38}$

Similarly, Thomas Vermeer found himself unable to marry Marge Cornell because she was already married and unable to divorce her husband, who was a prisoner of war. Thomas, at first, gave Marge money to help support their child but stopped when he was told that the money could be claimed by her husband. He then returned to the United States, canceled his agreement of support, and married an American woman who had been waiting for his return. Just before their marriage, Thomas's American fiancée wrote a letter to Marge recommending that she reconcile with her husband and get on with her life as they were getting on with theirs. Marge, for her part, claimed that Thomas and her husband, Ronald Cornell, had met and agreed that Cornell would divorce her so that she could marry Thomas. However, that process took at least two years. Left on her own after divorce, Marge had to rely on the help she obtained from her mother and her small wages, although those made her ineligible for public assistance. ${ }^{39}$

Most, but not all, of these efforts were met with failure, but even the successes did not secure long-term stability. The saga of the pursuit of Milton Hiatt illustrates how these personal disasters could entangle authorities at all levels and on both sides of the Atlantic. Milton Hiatt had married Joyce Costen during the war with the consent of American military authorities. Unfortunately, the marriage was invalid because Hiatt was already married. Hiatt refused to support the child of the purported marriage, now illegitimate by the bigamous status of the union, a legal anomaly that went unaddressed by legislation until 1959 (Kahn-Freund 1960). Costen wanted to start proceedings against the American Army since she held them responsible for her situation. British authorities did not wish to support

\footnotetext{
TNA FO 369/4051A, "Illegitimate Child of Miss Lydia Dixon and Mr. M. E. Rice."

TNA FO 369/4051A, "Paternity claim of Miss Doreen Shaughnessy".

See TNA HO 102/1363; HO 102/1364 for internal discussions about this issue.

TNA FO 369/4051A, "Case of Rosemary Harris and Clarence Woodrow Lamb."

TNA FO 369/4051C, "Illegitimate child of Mrs. M. Cornell and Mr. T. Vermeer."
} 
affiliation proceedings by Costen, since Florida required the presence of the petitioner in such actions. British officials worried about "the immense numbers of unmarried mothers who would want to follow suit and the ease with which the fulfillment of such orders are avoided in the U.S." ${ }^{\prime 4}$ In 1948, Costen involved her MP, Stanley Tiffany (Labour MP for Peterborough), and Tiffany in turn involved Foreign Secretary Ernest Bevin. Tiffany's pressure led to a thorough investigation undertaken by the Jacksonville consulate. When consular officials visited Hiatt's last known address, the occupants responded that they did not know him or his whereabouts but thought "he must be a person of some importance judging by the number of inquiries they get about him." They tried the American Veterans Administration (VA) authorities with no luck and reported: "Mr. White states that, when he last interviewed Mr. Hiatt, the latter stuck him as mentally unstable. Mr. White had the impression that any undertaking Mr. Hiatt gave to support Miss Costin's [sic] child would not be worth the paper it was written on." The Vice-Consul at Tampa shared this view, judging this case "another hopeless one." Consular officials persisted nevertheless, and two months later, they discovered that Hiatt had reenlisted and was stationed at McDill Air Force Base at Tampa. When they visited McDill, Hiatt had gone AWOL, but he was apprehended two months later. Consular officials returned to McDill where Hiatt's immediate commanding officer, the Adjutant General, and a consular official interviewed him. He admitted paternity of the child and "voluntarily" agreed to fill out the proper forms to give an allotment support to his child. Persistence proved successful in this case, at least to a limited extent. ${ }^{41}$

This case illustrates the transatlantic interpenetration of organizations to repair the damage wrought by war-time relationships gone wrong. At the top, such tangles could have political reverberations. On the ground, the determination of consular officials in combination with sympathetic American local authorities was also striking. Consular officials forged working relationships with local district attorneys, legal establishments, and social service agencies in their efforts on behalf of British war brides. On the other side of the Atlantic, a parallel hierarchy of different organizations, both governmental and private, existed. The Law Society, local aid bureaus, and the Red Cross advised single mothers and abandoned wives. These groups consulted with the Home Office, which in turn consulted with the Foreign Office, which in turn forwarded cases to consular officials, who then consulted with legal officials and social service agencies, Welfare Departments, and the American Red Cross, sending their findings back up the bureaucratic chain of command. Efforts to obtain maintenance for illegitimate children were often in vain, but officials had greater success in facilitating divorces.

\section{Divorce}

British observers frequently expressed concern about how the ease of obtaining an American divorce potentially harmed British wives who might wish to resist ending their marriages. Nevertheless, the evidence of the divorce cases preserved in Foreign Office records suggest that the ease of divorce, its comparatively low cost, and the recognition of broader grounds in the US helped British women who sought to end their short-lived marriages and get on with their lives. The consular files only hint at the size of the phenomenon. Although the files do not include a comprehensive accounting of the number of these cases or the total cost of the program, two quarterly reports by Florida consulates during 1948 suggest the scale and cost of providing legal aid to British wives of American servicemen. The statement of expenditure by the Miami consulate for the March quarter of 1948 totaled \$2102.90. This sum covered the legal costs of seventeen women, whose individual costs ranged from a low of $\$ 35$ to a high of $\$ 307.90$. This total might be further reduced by sums recovered from the husbands, which consulate legal advisers routinely sought. For that same quarter, the statement showed a further $\$ 416.00$ for cases overseen by the Jacksonville consulate, which covered the costs of four more British

40 TNA FO 369/4051B, “Marriage of Miss Joyce Costen and Milton O. Hiatt," Jackson memo, 15 June [1948].

41 TNA FO 369/4051B, “Marriage of Miss Joyce Costen and Milton O. Hiatt." 
wives, whose expenditures ranged from a low of $\$ 70$ to a high of $\$ 200 .{ }^{42}$ A further statement by the Jacksonville consulate in October 1948, recorded $\$ 646.00$ of legal costs for five more women whose expenses ranged from $\$ 73$ to $\$ 200 .{ }^{43}$ Such relatively modest sums might well have been within the means of others who wished to end their marriages.

June Peters managed to obtain a divorce on her own, for instance, but she had trouble returning to the UK. June's mother wrote to the Foreign Office about her daughter's plight in June 1948. Mrs. Peters had married an American serviceman in England three years before, and they had one child, born in England. They settled in Detroit, where Mrs. Peters divorced her husband for infidelity. Unfortunately, Peters refused to pay court-ordered alimony, and he left Michigan with another woman to live in California. June Peters worked for food and board looking after six children, so she could not save money for the journey home. The Detroit Consul General estimated that the cost of repatriation was about $\$ 270$, or $£ 65$ to $£ 70$, and asked June Peters' mother if she could pay back that sum if British officials advanced it to her daughter. Mrs. Sawyer replied: "We are only a working-class family" but could manage weekly payments of $£ 2$. The Foreign Office found those terms agreeable and made arrangements for the repatriation of Mrs. Sawyer's daughter and grandson. In November 1948, Mrs. Sawyer wrote again: "Enclosed please find two Post Orders for the value of $£ 2$. I am pleased to say that my daughter and grandson arrived home safely on the 2nd of November, for which I thank you very much." 44

Sometimes the families of husbands stepped in on behalf of daughters-in-law. This formed one element of the divorce of Lucy Rohrabaugh overseen by the Denver consulate towards the end of 1948 . Lucy had married John George Rohrabaugh, Jr., a private in the U.S. Army, in May 1945 and since then the couple had two children, one born in Britain and one born in the United States. Consular officials described Rohrabaugh as "unstable and erratic," and they were anxious that Lucy get a divorce and return home. The file hints at the husband's mental instability by noting the status of Rohrabaugh's mother as a mental patient and the expectation that Rohrabaugh himself might undergo psychoanalysis. Consular officials sought authorization for funds for legal fees and for repatriation. Lucy's parents were dead, and she had no family in Britain to help her. Legal advisors assured consular officials that they were confident that she could obtain a divorce quickly under Colorado law, so those funds would be put to good use. Rohrabaugh himself offered to pay $\$ 15$ per month maintenance towards the children, legal advisors sought reimbursement of divorce costs of $\$ 135$ from him, and, in addition, Rohrabaugh's father offered $\$ 500$ to defray his daughter-in-law's travel costs back to England. The last document in the file is a telegram to arrange for someone to meet her and her children when she arrived at Southampton, 31 January $1949 .{ }^{45}$

Wives seeking maintenance for themselves and their children from estranged American husbands did not fare any better than those single mothers who sought maintenance. In many of these cases, wives had failed to come to the United States in the first place or had returned home to the UK, leaving their husbands behind. American husbands believed they need not maintain wives who refused to live with them. The wife of Victor Mahair claimed in 1948 that she had not heard from her husband since his return to the USA six months after their 1945 marriage. When Consular officials in Boston contacted Mr. Mahair at his home in New Hampshire, he told them that after he sent her money to join him, she replied that she could not leave her mother and sister at that time. Mahair, a Catholic, did not wish to pursue a divorce, but he also would not support his wife as long as she lived separately from him. ${ }^{46}$ Similarly, John Strickland of Sweetwater, Tennessee refused to support his wife unless she gave him custody of their child. Mrs. Strickland had written that she would "never, never come to America,"

42 TNA FO 369/4051B, “Lawyer's fees and debts incurred on behalf of G. I. Brides,” March 1948.

43 TNA FO 369/4051C, "Expenses for legal aid to G. I. Brides involved in divorce cases," 21 October 1948.

44 TNA FO 369/4051B, "G. I. Bride-daughter of Mrs. J. Sawyer."

45 TNA FO 369/4051C, "G. I. Bride-Mrs. Lucy Rohrabaugh."

46 TNA FO 369/4051A, "G. I. Bride-Mrs. Mahair." 
and her documented refusal to join him gave him grounds for divorce in Tennessee. ${ }^{47}$ In March 1948, Joyce Wilcox expressed shock and surprise when her American husband filed for divorce in the United States after she twice postponed her journey to join him. Sam Wilcox's residence in Anderson, Indiana meant that the Chicago consulate monitored the case. Wilcox's lawyer gave the husband's point of view: "As grounds for divorce, the plaintiff alleges that the defendant has repeatedly promised him that she would come to the United States to live as his wife, but that all such promises have been broken. That since leaving England the plaintiff had insisted, and in fact, has begged, the defendant to come to the United States, but that despite her repeated promises to do so the defendant refused to leave her family in England and join the plaintiff in this country. The complaint alleges that the defendant's consistent refusal to come to this country and the continued breaking of her promises to come constitutes such mental cruel and inhuman treatment as makes it impossible for him to continue as her husband ...." ${ }^{\prime 48}$

Wives who came to the United States and then returned to the UK without first settling their status found themselves in an even more difficult situation, without much recourse in either country. When Mrs. M. A. Hooser of Norwich asked for help in gaining support from her husband for herself and her daughter, consular officials in Cincinnati were pessimistic. Mrs. Hooser's application for public assistance in Norwich combined with her letter to the consulate triggered an inquiry into her case, and Cincinnati asked the Red Cross to investigate the home situation for them. The Red Cross report reflected the husband's view of events, which naturally differed significantly from his wife's. He intended to get a divorce, and, although he had offered her a cash settlement, she insisted on receiving ongoing maintenance for life. However, she could do little to contest his case unless she was present in the USA. In the meantime, she might have to rely on assistance from UK organizations. A consular official wrote to her: "I am very sorry indeed that you should have run into all this trouble, trouble which you might perhaps have avoided had you made yourself known to us while you were living in West Virginia and given us the opportunity to advise and assist you while you were still in this country. Now that you have left the United States, I am afraid that our ability to help you is limited to keeping you informed of your husband's intentions and advising you of the steps you should take to protect your interests and those of your child when the matter is, on your husband's initiative, brought before the court." With that, they sent her to the Law Society for legal advice. ${ }^{49}$ Similarly, Laura Almgren, of Warrington, Lancashire, returned home in November 1946 against the advice of the New York City consulate. Her husband did not send her any support, so early in 1947, she asked for help from the consulate to obtain a response from him. When letters from the consulate to Mr. Almgren went unanswered, officials turned to the International Social Service (ISS) and the Community Service Society of New York to trace Almgren. Their inquiries revealed that his view of their separation did not match the narrative given by his wife to consular officials. She had portrayed their break as amicable, but he had been deeply hurt by her return to the UK. Almgren had paid for an abortion so that she could "go back to England as she had come," and had paid for her transportation home, so he was not interested in sending her more money, even if he had any. After his wife left, Almgren had quit his job and traveled around the country doing odd jobs, which explained both his failure to reply to the letters sent to him by the consulate and his lack of the resources to maintain his family in England. Both the ISS and the Community Service Society expressed concern about Almgren's emotional wellbeing, but he rejected their offers of counseling. The report by the ISS suggested that only flexibility on the part of Mrs. Almgren combined with direct communication of the spouses could provide any remedy; consular officials agreed with this assessment but doubted whether either spouse would reach such an accommodation. ${ }^{50}$ 
Consular officials, as the Florida reports suggest, could have success in facilitating divorce, but they were often unable to obtain ongoing maintenance for divorced wives. The case of Amelia Weillie, which came under the jurisdiction of the San Francisco consulate, illustrates a case protracted by the refusal of the parties involved to submit to the advice and direction they received from authorities. Amelia Weillie married Harold Weillie in January 1945. Claiming to be a widow, she already had a son, Michael. Mother and son came to America in March 1946, but Weillie never provided adequate support either to them or the two children the couple had together. Amelia filed warrants for non-support, Harold disappeared, and the local Welfare Department had to take on the support of the family. In response to an inquiry from the Welfare Department, the British consulate recommended that Amelia might proceed with a divorce in the United States and that she might be eligible for aid. In addition, the UK could provide support for repatriation, at least for her and her eldest son, as both were still British citizens. The Welfare Department, the British Consulate, and the local District Attorney all co-operated to help Amelia get her divorce. Legal aid was authorized in August 1948, and her father offered her a home if she returned to England. All went well until September 1948. At that point, Harold returned, and the couple reconciled, bringing the prospect of a divorce to a halt. However, Harold refused to make a home for young Michael, and he was placed in a licensed boarding home while efforts to return him to England continued. Amelia's parents and sister confirmed their willingness to take Michael. During these repatriation efforts, the authorities discovered that Michael was illegitimate, as they found his birth certificate but no marriage certificate for the first marriage claimed by Amelia. This did not alter their interest in Michael's case, as he was still a British citizen, but they suggested that American immigration authorities might be willing to pay for his transportation. While they are looking into this, the relationship between the Weillies broke down again, and Amelia renewed her interest in a divorce in spring 1949.

This time the divorce took place. Consular officials arranged for legal representation and paid the fees. They suggested that the divorce decree grant Amelia full custody of all three children so that they could return to England together, and they further requested that the husband reimburse these sums. The case was heard on 19 August 1949, and a decree was granted as of 24 August. Amelia was back in England with her family on 16 October, but the glow of a family reunion apparently did not last very long. In February 1950, the San Francisco consulate received a letter from Amelia that asked: "if you could help my 2 children and myself return to my husband Mr. Weillie, maybe I am asking an awful lot of you but since my return to England I have found my children and I are not wanted, and it means me having to put my 2 babies which are American citizens into a home, my folks have offered to take care of my Son which was born over here if I can get back to the U.S.A. with the babies." Harold had offered to take them all back, she explained. The consulate replied by pointing out the mistreatment that she herself had testified to, concluding that they could not offer any assistance for her to return to him. An internal memo on the case observed: "If we were foolish enough to offer her any assistance to return here the whole process would begin anew in six months' time." The memo continued: "You will recall that in our letter of the 12th July last on the case of Mrs. Nan L. Taylor we suggested that the time had come to reconsider the assistance that should be given to war brides in this country claiming to be distressed. In many cases, this one included, the net result of all work and expense is that the woman is more dissatisfied than before and wishes to return here to the squalor and alleged misery which she appeared so anxious to leave. We ... must reconsider whether, in many of these cases, our charity is not being seriously misplaced."

Consular officials continued to press Harold Weillie for reimbursement of the costs of the divorce and repatriation. They made no progress until he enlisted in the American Navy in 1951, which gave him a regular income. In the meantime, Amelia continued her efforts to return to him; efforts thwarted by the Foreign Office by the simple expedient of withholding her passport until she paid off her debt. However, the Weillies managed to do so by the end of 1951. Amelia obtained her passport in January 1952 and returned to her erstwhile husband. This reconciliation, as predicted by the civil servants, did not last long. In October 1953, Harold inquired about assistance for his wife and their now five 
children to return to England. The Consular office refused to be drawn in this time. An internal memo observed: "It is abundantly clear that the predictions of our predecessors (and the Foreign Office) were $100 \%$ correct." ${ }^{\prime 51}$ Amelia had pushed the legal aid program intended to alleviate the disadvantages suffered by British war brides further than it would go, and she would not again receive the same support she had previously. The late date of her last letter also indicated that the patience with war brides waned by the mid-1950s.

\section{Conclusions}

Thousands of British women married foreigners during World War II. Their marriages occupied a liminal position between the family disruptions of the war and the post-war emergence of the companionate family ideal during the 1950s (Finch and Summerfield 1991; Collins 2003; Thane 2003; Langhamer 2006; Weeks 2007, pp. 23-56). The British war bride married to an American serviceman engendered particular anxiety. Although British women who dallied with foreign servicemen during the war were regarded with disapproval as "goodtime" girls (Rose 1997, pp. 71-106), with married women coming under particular scrutiny, British authorities responded with patriarchal protectiveness to the perceived postwar plight of the young women who married American servicemen during the war. Policies to carry out this duty, in tension with longstanding legal practices that purposefully ejected women who married foreigners from full citizenship status, sought to fold those whose marriages failed back into the nation. Officials in London and consular officials across the United States worked to provide help to these women, despite the perceived hopelessness of doing so. Like the British view of the American G.I., the American image of the British war bride exhibited some ambivalence (Friedman 2007). Nevertheless, the evidence of these illustrative case files shows the extent to which British war brides also enjoyed American sympathy and the extensive cooperation offered to British efforts to help them. These cases also point to the role of emotionality, both in policymaking inflected by sympathy or antipathy and in the work to carry out a policy with respect to people in the grip of disappointed love, anger, regret, and/or homesickness. Those officials who sought to help often responded in irrational, rather than rational ways, confounding those who wished to assist them. Most notably, the individuals in the cases taken up by consular officials also contradicted stereotypes of both husbands and wives. The ideological elements of the images of both the goodtime girl and the victimized bride proved inadequate. In addition, the view of American soldiers as much better off than their British counterparts led the British to overstate these men's ability to support divorced wives or illegitimate children. The prosperity of soldiers soon disappeared after the war, a problem that was particularly acute with men supporting other families in the USA. As consular officials perhaps understood from experience, actual people led lives more complicated than those suggested by any of these stylized stereotypes.

Funding: This research received no external funding.

Conflicts of Interest: The author declares no conflict of interest.

\section{References}

Allport, Alan. 2010. Demobbed: Coming Home after the Second World War. New Haven: Yale University Press. Anon. 1950. The Matrimonial Causes (War Marriages) (Appointed Day) Order, 1950. The International Law Quarterly 3: 417-18.

Baldwin, M. Page. 2001. Subject to Empire: Married Women and the British Nationality and Status of Aliens Act. Journal of British Studies 40: 522-56. [CrossRef] [PubMed]

Bellush, Bernard. 1968. He Walked Alone: A Biography of John Gilbert Winant. The Hague: Mouton.

51 TNA FO 600/41, “Amelia Weillie." 
Bland, Lucy. 2019. Defying racial prejudice: Second World War relationships between British women and black GIs and the raising of their offspring. Women's History Review 28: 853-68. [CrossRef]

Collins, Marcus. 2003. Modern Love: Personal Relationships in Twentieth-Century Britain. Newark: University of Delaware Press.

Coward, Noèl. 1954. Future Indefinite. New York: De Capo Press, Inc.

Ferguson, Sheila, and Hilde Fitzgerald. 1954. Studies in the Social Services. London: HMSO.

Field, Geoffrey. 1990. Perspectives on the Working-Class Family in Wartime Britain, 1939-1945. International Labor and Working-Class History 38: 3-28. [CrossRef]

Finch, Janet, and Penny Summerfield. 1991. Social Reconstruction and the emergence of companionate marriage, 1945-1959. In Marriage, Domestic Life and Social Change; Writings for Jacqueline Burgoyne 1944-88. Edited by David Clark. London: Routledge, pp. 7-32.

Friedman, Barbara G. 2007. From the Battlefront to the Bridal Suite: Media Coverage of British War Brides, $1942-1946$. Columbia: University of Missouri Press.

Goodman, Phil. 1998. 'Patriotic Femininity': Women's Morals and Men's Morale During the Second World War. Gender \& History 10: 278-93.

Graveson, Ronald Harry. 1950. Jurisdiction, Unity of Domicile and Choice of Law under the Law Reform (Miscellaneous Provisions) Act, 1949. The International Law Quarterly 3: 371-90.

Kahn-Freund, Otto. 1960. Legitimacy Act 1959. The Modern Law Review 23: 56-60.

Keshen, Jeffrey A. 2004. Saints, Sinners, and Soldiers: Canada's Second World War. Vancouver: University of British Columbia Press.

Langhamer, Claire. 2006. Adultery in Post-War England. History Workshop Journal 62: 86-115. [CrossRef]

Modell, John, and Duane Steffey. 1988. Waging War and Marriage: Military Service and Family Formation, 1940-1950. Journal of Family History 13: 195-218.

Olson, Lynn. 2010. Citizens of London: The Americans who Stood with Britain in its Darkest, Finest Hour. New York: Random House.

Reynolds, David. 2000. Rich Relations: The American Occupation of Britain 1942-1945. London: Phoenix Press.

Reynolds, David. 2007. Churchill's Government and the Black GIs, 1942-43 in From World War to Cold War. Oxford: Oxford University Press, pp. 199-216.

Rose, Sonya O. 1997. Girls and GIs: Race, Sex, and Diplomacy in Second World War Britain. The International History Review 19: 146-60. [CrossRef]

Rose, Sonya O. 1998. The 'Sex Question' in Anglo-American Relations in the Second World War. International History Review 20: 884-903. [CrossRef]

Rose, Sonya O. 2003. Which People's War? National Identity and Citizenship in Britain, 1939-1945. Oxford: Oxford University Press.

Saunders, Kay, and Helen Taylor. 1995. The Reception of Black American Servicemen in Australia during World War II: The Resilience of 'White Australia'. Journal of Black Studies 25: 331-48. [CrossRef]

Smith, Graham. 1987. When Jim Crow Met John Bull: Black American Soldiers in World War II Britain. London: I. B. Tauris.

Stone, Lawrence. 1990. Road to Divorce: England 1530-1987. Oxford: Oxford University Press.

Thane, Pat. 2003. Family Life and "Normality" in Postwar British Culture. In Life after Death: Approaches to a Cultural and Social History of Europe during the 1940s and 1950s. Edited by Christof Mauch and David Lazar. Cambridge: Cambridge University Press, pp. 193-210.

Thane, Pat, and Tanya Evans. 2012. Sinners? Scroungers? Saints? Unmarried Motherhood in Twentieth-Century England. Oxford: Oxford University Press.

Topping, Simon. 2013. 'The Dusky Doughboys': Interaction between African American Soldiers and the Population of Northern Ireland during the Second World War. Journal of American Studies 47: 1131-54. [CrossRef]

Urquhart, Fred. 1951. Jezebel's Dust. London: Methuen.

Webster, Wendy. 2013. 'Fit to Fight, Fit to Mix,' sexual patriotism in Second World War Britain. Women's History Review 22: 607-24. [CrossRef] 
Weeks, Jeffrey. 2007. The World We Have Won. London: Routledge.

Publisher's Note: MDPI stays neutral with regard to jurisdictional claims in published maps and institutional affiliations.

(C) 2020 by the author. Licensee MDPI, Basel, Switzerland. This article is an open access article distributed under the terms and conditions of the Creative Commons Attribution (CC BY) license (http://creativecommons.org/licenses/by/4.0/). 